the 'global approach'. This approach is to be taken all the more seriously given religious ambiguity. McKim also outlines an approach to salvation which he calls 'reclusivism', an approach which recommends being open minded about the extent to which salvation is available outside a given religious tradition.

Much of McKim's work has been seen before but the arrangement in one volume does give rise to some new material, for example, in the epilogue. McKim is notably non-committal in his work and is even careful to avoid claiming that he has shown religion to exhibit extremely rich ambiguity. However, not committing to a particular view on religious truth or salvation does tell of McKim's own eagerness to explore the religious traditions with an open mind and to evaluate them by means of how open they are to this type of exploration and to each other, as well as to religious ambiguity.

The prolegomena approach to religious diversity has also been seen before in Peter Byrne's Prolegomena to Religious Pluralism: Reference and Realism in Religion (Basingstoke: Macmillan, 1995). While Byrne's work was grounded in Rom Harrés philosophy of science and Michael Devitt's philosophy of language, McKim's work is grounded in his study of the religious traditions. Clearly written with many interesting religious anecdotes, On Religious Diversity will prove to be a helpful book for anybody wishing to think through an epistemological and soteriological response to religious diversity.

\title{
IEUAN LLOYD
}

University of Birmingham

\section{Mikel Burley. Contemplating Religious Forms of Life: Wittgenstein and D. Z. Phillips. Continuum, 2012.}

Mikel Burley's book is an ideal volume for those who wish to understand the views of Wittgenstein and D. Z. Phillips on the philosophy of religion. What strikes one initially is the opening sentence of the introduction: 'This book is about the work of two men whose contributions to the study of religion over the last hundred years have been pre-eminent: Ludwig Wittgenstein (1889-1951) and D. Z. Phillips (1934-2006)'. Burley is right in choosing these two philosophers, but Phillips would 
have been embarrassed with this introduction. He would see himself as a disciple of Wittgenstein rather than his equal, though it is true that Phillips was considerably more - though not exclusively - concerned with religion during his life than was Wittgenstein. Another way of putting this is to say that, were it not for Wittgenstein, Phillips could not have written what he did. Even so, it would be difficult to overstate the significant effect that Phillips has had on the world of philosophy of religion, both through his extensive publications and through his contributions to the many conferences that he attended and organised in Europe and the USA.

Structurally, the book consists of two equal parts, with three chapters devoted to each of the philosophers, followed by a concluding chapter. The origin of the book lies in papers or presentations previously published and delivered between 2007 and 2012. Burley's exposition of Wittgenstein and Phillips is largely apologetic, but not without some criticism, which occurs mainly in one particular chapter on Phillips. The views of each thinker are expressed with clarity, and the views of their opponents presented without distortion. Most of my remarks will be devoted to the part on Phillips.

Wittgenstein's and Phillips' approach to philosophy is 'contemplative, by which is meant that the emphasis is on understanding the meaning of religious language as it is found in specific contexts, in contrast with the truth of its statements, which occupies the interest of most philosophers of religion. Burley brings out this difference well by discussing examples, which is the meat of the Wittgensteinian method. Cool contemplation may be a pastime for some and a spiritual activity for others, but for both thinkers it is the only correct way of doing philosophy. It requires one to enter the world of another, in order to do justice to what is going on in any particular practice; yet, at the same time, the method requires that one 'leave everything as it is'. Phillips calls this position philosophy's 'cool place. Burley agrees with this approach, but he thinks that Phillips does not always stick to his brief, in particular when he describes some beliefs as 'shallow' or 'deep', which makes his position qua philosopher warmer than he intends.

Wittgenstein said little about Christianity, so Burley has to confine himself to Wittgenstein's writings on the work of Frazer's Golden Bough, where he brings out the difference between the former's attention to description and contrasts it with the latter's attention to purpose and explanation, especially in the understanding of 'ritual'. The writings of 
some sympathisers of Wittgenstein are considered, such as Peter Winch and his much-discussed paper, 'Understanding a Primitive Society', as well as the views of Frank Cioffi and Howard Mounce. In chapter 2, 'Absolute Safety', Burley finds a difference between Wittgenstein and Winch on absolute safety in connection with religion and morality. In chapter 3, Burley provides a long but useful and telling criticism of Severin Schroeder's claim that Wittgenstein (and Phillips, it would follow) advocates an expressivist view of religious belief. This occupies some 24 pages.

In Part 2, Burley rightly begins a discussion of Phillips with a chapter entitled 'Beyond Realism and Non-Realism'. Rightly, because it is this topic that occupies the attention of Phillips' dissenters, who usually want him to come clean on whether he is a realist or a non-realist. This is fully evident in Kai Nielsen's and Phillips' jointly authored book, Wittgensteinian Fideism, and also in the writings of John Hick, Phillips' predecessor at Claremont Graduate University. Burley's defence throughout is that neither Wittgenstein nor Phillips can be fitted into either pigeon-hole, in spite of the impatient attempts of their opponents. He finds that the latter share a common error, viz., that they do not consider religious beliefs in their natural habitat. As Wittgenstein puts it: 'What we do is to bring words back from their metaphysical to their everyday use.'(Philosophical Investigations, \$ 116) But Phillips says that, even if he were to use their language of realism, non-realism, evidence, proof, it would not mean that he would be any closer to their views, for the meaning of these words would differ in different contexts. For Phillips, his opponents' two positions do not exhaust the possibilities. Beside the realism of Hick and the non-realism of Cupitt, there is the possibility of seeing the language of religion as sufficient in itself. The pictures we have in religion have a meaning which does not depend on some external reality. Nor is that meaning an attitude dressed up in realist clothes. As Wittgenstein puts it, the truth is in the pictures. This is sometimes a difficult idea to get across, and one which has led some to ask: if the idea of God lies in the picture, does God die with the disappearance of that picture? The reason why this point of view is so implausible to non-philosophically inclined Christians is that they take Phillips to be guilty of some sleight of hand in translating such events as the nativity story, the miracles, the resurrection and the ascension, into non-historical language. Yet Phillips at times claims that far from changing what the ordinary believer believes he is truly representing not revising their beliefs. So far, Burley goes along 
with Phillips. But in the next chapter, 'Contemplating Eternal Life', he distances himself from some of Phillips' views. This occurs mainly in the section 'Against Survival'. Here, Phillips appears to have touched a raw nerve in Burley, who now employs a critical vocabulary that one would not have expected to find in his phrase book. He sees 'danger in Phillips' approach' (p. 112), which is too quick 'to dismiss temporal conceptions of immortality' (p. 111), argues that Phillips can lack 'critical evaluation' (p. 110), is guilty of 'philosophical hubris' (p. 114) and, worse still, fails to examine 'the lives of people within the relevant cultures themselves' (p. 114). Physician heal thyself! Is Burley having a change of heart towards Phillips? What has raised his temperature is that the latter has confined himself to Christianity - as if that would be sufficient to yield an understanding of religious beliefs in general. The issue in question is the matter of reincarnation. Up to this point, Burley - along with Phillips - has shunned the metaphysical and the temporal features of the after-life, but he finds that Phillips' views are wanting when one considers the ideas of Hinduism and Buddhism. Burley reminds us that we cannot ignore 'the beliefs of many millions of Hindus and Buddhists' (pp. 113,114). Strangely, Burley was not so ready to raise the same objection concerning the belief - addressed in the previous chapter - of vast numbers of Christians in the afterlife. Phillips can make the views of Christians look silly when he presses on them positivist questions relating to personal identity, such as 'What is a baby or an octogenarian going to look like in heaven?' What, then, has happened to Wittgenstein's advice - usually in Phillips' repertoire - that what is ragged must be left ragged? Those who believe that life continues hereafter may stammer and stumble when a philosopher asks for details of that continued existence. But does not Burley's own discussion of reincarnation - and in spite of what he has said in the previous chapter - propose the continued existence of souls as a form of personal continuity post mortem? Has not the metaphysical reappeared, even though John Haldane's position that the metaphysical is not necessarily in opposition to the religious was dismissed earlier? Lest it be said that Phillips has philosophers of religion in his sights, rather than the ordinary believer, it is worth pointing out that such philosophers are not like particle physicists who speak in their academic capacity of tables as not being solid, but who are quite happy to complain (without contradiction) to a waiter in a restaurant that their table is not steady. For many philosophers of religion are ministers of 
the cloth who use the same language in the study as at the altar. Is there a tension between Burley's view of the Christian's idea of the after-life and that of the Buddhist and Hindu?

Burley goes on to discuss Phillips' moral objection - influenced by Simone Weil - to the belief in a temporal view of the afterlife. This belief is seen to have a corrupting effect on our moral life, in that it is thought to weaken the moral effect of the finality of death, as it goes along with a compensatory view of the life hereafter, when injustices can be recompensed. But surely the Day of Judgement is not just meant to compensate for one's sufferings on earth, it also is a time when the integrity of one's life on earth is judged. It is a time of reckoning - hardly a comforting thought. In fact, one could claim that a belief in the finality of death could be seen as a form of escapism. Perhaps Burley's criticism of Phillips here could be summed up by saying that the latter has spoken of the grammar of immortality, rather than $a$ grammar of immortality.

Phillips studied literature in university before he turned to philosophy, and he retained an interest in it throughout his life. Burley's chapter 'Philosophy of Religion through Literature' (ch. 6) is unique in revealing the extent to which Phillips resorted to his knowledge of literature to expound and illustrate his understanding of religion. In this chapter, Burley discusses Phillips' thoughts on Larkin, Tennyson, Beckett, C. S. Lewis, Edith Wharton and Simone Weil, but he thinks that, at times, Philips can be charged with interpreting their ideas to fit with his own. This is an important chapter in the study of Phillips' dependence on literature in his thinking.

Some final comments on important omissions. There is little mention of the label that Kai Nielsen pinned on Phillips, which stuck to him however often he rebutted it, viz., that of being a fideist. I was also surprised not to find in Burley's book much more about the influence of Rush Rhees on Phillips. Phillips regarded Rhees as his most influential teacher, edited 16,000 pages of Rhees' manuscripts, published a number of books from these, and, of course, corresponded with him. It is a pity, too, that there is no reference to the excellent volume $D$. Z. Phillips' Contemplative Philosophy of Religion (Aldershot: Ashgate, 2007), edited by Andy Sanders, in which six philosophers of religion present their criticisms of Phillips, followed by what turned out to be his final responses to his opponents. Regrettably, Phillips did not see the publication of this book. In spite of these omissions, Burley has presented 
us with an excellent volume, which will help continue to keep alive the huge contribution that Wittgenstein and Dewi Phillips have made to the study of philosophy of religion.

\section{CHAD MCINTOSH}

Cornell University

\section{Linda Zagzebski. Omnisubjectivity: A Defense of a Divine Attribute. Marquette University Press, 2013.}

When I first read Thomas Nagel's 'What Is It Like To Be A Bat?' immediately I wondered, 'Does God know what it's like to be a bat - or me?' In her 2013 Aquinas lecture, Linda Zagzebski answers in the affirmative, arguing that God has 'omnisubjectivity', the 'property of consciously grasping with perfect accuracy and completeness every conscious state of every creature from that creature's first person perspective' (p. 10). Two distinct but intersecting tracks can be discerned throughout this small book, one defensive and the other exploratory. The former defends the possibility of omnisubjectivity by advancing a model that seeks to demonstrate how God can be omnisubjective; the latter explores the attribute's scope, relation to other divine attributes, and practical significance to believers. Consider each in turn.

It seems impossible that anyone but me could know what it's like for $m e$ to see red or taste a strawberry. A friend and I could see and taste the same strawberry, but we could never have qualitatively identical experiences, which seem essentially private to our own conscious perspectives. But if this were so, argues Zagzebski, God would not know all there is to know about creation. Even if God were omniscient and knew all the objective facts about the world, 'perhaps the most important feature' (p. 13) would be left out: the what-it-is-likeness of creaturely experience. This is unbecoming of the Christian God who, from an Anselmian perspective, is not merely omniscient but cognitively perfect. God must therefore 'grasp what it is like to be his creatures and to have each and every one of their experiences' (p. 15).

Zagzebski considers two models of how God could 'grasp' creatures' mental states. According to the first, God's consciousness merges or overlaps with creatures' consciousnesses. So when I see and taste 